\title{
Application of Government's Responsibility in Compliance of Community Rights in The Food Area in The District TTS Province Nusa Tenggara Timur
}

\author{
Jeane Neltje Saly ${ }^{1}$ \\ \{jeaneneltje@gmail.com/ jeanes@fh.untar.ac.id $\left.{ }^{1}\right\}$ \\ Tarumanagara University, Indonesia ${ }^{1}$
}

\begin{abstract}
The problem is what obstacles the implementation of government responsibility create enough food for the people, and how efforts are made for food sufficiency, in the Soe district of Timor Tengah Selatan/ TTS . The research method used is empirical juridical by using primary data besides secondary data. The data obtained through observation techniques and interviews, so that the data obtained are analyzed quantitatively and the conclusions are taken inductively. The results of the study are in addition to geographical conditions, rainfall, clean water, human rettssources are still far from expectations both in quality and quantity, as well as transportation for communication from village to village next to the marketing location challenges as well as increasingly complex food, change from time to time as a result of being influenced by local and global specific matters. Efforts made by Local Government to achieve food self-sufficiency through local produce, among others, in the form of institutional strengthening. and business development followed by post-independence stages in the form of General Guidance Sharpening with Stronger and Measurable Output in stages to meet the needs of the community, and with the desire to be exported, at least in order to enjoy the ASEAN community market.
\end{abstract}

Keywords: Food, Government Responsibility.

\section{Introduction}

\subsection{Background Issues}

Problematic implementation of government responsibility in the field of food security is one of the obstacle aspects of the State in the welfare of the people to realize the goal of the formation of the State Government, set out in the Preamble of the 1945 Constitution $^{1}$ Particularly in Soe Regency of Timur Tengah Selatan (TTS), where the application of local food becomes an issue that has not been completed optimally, resulting in malnutrition, especially toddlers, which also occur in almost all countries in the world, on Global Nutrition Report.

\footnotetext{
${ }^{1}$ Pembukaan Undang-Undang Dasar Negara Republik Indonesia ke-4, yang berbunyi: "Lebih dari itu untuk membentuk sebuah Pemerintah Negara Indonesia yang melindungi seluruh bangsa Indonesia dan keseluruhannya tumpah darah Indonesia dan untuk memajukan kesejahteraan umum, mendidik kehidupan berbangsa, ... dst
} 
The Global Nutrition Report shows that Indonesia ranks 108th in the world with the most severe malnutrition cases resulting in inhibition of physical growth of toddlers, but also affects the internal organs of the body above. Laos (124) and Timor Leste (132). Indonesia's position is even higher among ASEAN countries, such as Thailand (46) Malaysia (47), Vietnam (55), Brunei (55), Philippines (88), even Cambodia.

One of the ways in carrying out its responsibilities is that the government implements the fulfillment of food towards the realization of self-reliance and food security. As an archipelagic country whose geographical patterns vary, food fulfillment is done through local food production.

Its implementation faces the alteration of processes and the way in which order is made. In order to run in an orderly manner, then the law is used as the basis, in accordance with the view of Mochtar Kusumaatmadja that the law should be used as the foundation in the implementation of development that moves to change and improve ${ }^{2}$.

The legal basis for the implementation of food is regulated in Law No. 18 of 2012 on Food (Act No. 18.

The philosophical considerations is that:

"Food is the most basic human needs and fulfillment is part of human rights guaranteed in the 1945 Constitution of the State of the Republic of Indonesia as a basic component to realize qualified human resources.

Yudicial Considerations is that:

The State shall be obliged to realize the availability, affordability and fulfillment of adequate, safe, quality, and nutritious food consumption both nationally and regionally and personally evenly throughout the territory of the Unitary State of the Republic of Indonesia at all times by utilizing resources, institutions and culture local".

The sociological consideration is that:

"as a country with a large population and on the other hand having diverse natural resources and food sources, Indonesia is able to fulfill its food needs sovereignly and independently"

UU No. 18/2012 About Food determines that what is meant by:

"Food is anything that comes from biological sources of agricultural, plantation, forestry, fishery, livestock, aquatic and water products, whether processed or unprocessed for food or drink for human consumption, including Food additives, Foodstuffs, and other materials used in the process of preparing, processing, and or the manufacture of food or drink dan/atau pembuatan makanan atau minuman"3.

Food is a basic component for the realization of quality human resources, is the most basic human needs and fulfillment is part of human rights guaranteed in of the 1945 Constitution of the State of the Republic of Indonesi ${ }^{4}$.

\footnotetext{
${ }^{2}$ Mochtar Kusumaatmadja, Fungsi Hukum Dalam Pembangunan Nasional, BinaCipta, 1978,hal.11

${ }^{3}$ Pasal 1 angka 1 Undang-Undang Nomor 18 Tahun 2012 tentang Pangan

${ }^{4}$ Konsiderans Undang-Undang Nomor 18 Tahun 2012 tentang Pangan, huruf a
} 
This is reflected in the General Explanation of Law no. 18 on Food, that: in the implementation of national development which is a reflection of the will of all people to continuously improve their prosperity and welfare fairly and equally in all aspects life that is done in an integrated, directed, and sustainable manner in order to realize a just and prosperous society, both material and spiritual based on Pancasila and of the 1945 Constitution of the State of the Republic of Indonesia ${ }^{5}$.

The purpose of the Food Arrangement is to meet basic human needs that provide benefits in a fair, equitable and sustainable manner based on Food Sovereignty, Food Self-Reliance and Food Security ${ }^{6}$.

The purpose of arranging the organization of Food is set forth in the norm of Article 3, that is "Food Implementation is carried out to meet basic human needs that provide benefits in a fair, equitable, and sustainable manner based on Food Sovereignty, Food Self-Reliance, and Food Security

Furthermore, in the norms of Article 4, among others, it is stipulated that "The Implementation of Food aims to:improve the ability to produce food independently, provide a variety of food and meet the requirements of security, quality, and nutrition for public consumption, and realize the level of sufficiency of Food, especially Staple Food at reasonable and affordable prices in accordance with the needs of society ${ }^{7}$.

The norm above shows the desire of the government to invite the people together prospering themselves through local food. However, the purpose of prospering the people through the subsequent food sufficiency on self-sufficiency and food security through local food has not been achieved optimally.

However, the situation indicates the number of cases of hunger, malnutrition and malnutrition that sporadically still occur in various regions of Indonesia, from Aceh, Riau, Lampung, West Java, East Java, NTT, NTB, South Sulawesi, West Papua and other areas .

This situation also occurs in the world, although food security in the United Nations Food Policy Resolution launched in 1996 at the World Food Summit, that food can guarantee the survival of human life, not a guarantee. In fact, hunger still threatens the citizens of the world including Indonesia. The concept of food fulfillment that is left to the market mechanism actually worsen the situation. Although the government's efforts to carry out its responsibilities are to address cases of hunger or food scarcity, it is only temporary and even has the potential to add new problems such as rice imports and raskin programs.

The Report of this research would like to answer the obstacles in the implementation of government responsibility to create enough food for the people to support their welfare, and government efforts in implementing adequate food for the welfare of the people in Soe District TTS

\subsection{Problem Formulation}

1. What is the obstacle in the implementation of government responsibility to create enough food for the people to support their welfare?

\footnotetext{
${ }^{5}$ Indonesia, Undang-Undang Nomor 18 Tahun 2012 Tentang Pangan, Penjelasan Umum, Alinea 1 dan 2

${ }^{6}$ Penjelasan Umum, Undang-Undang Nomor 18 Tahun 2012 tentang Pangan

${ }^{7}$ Pasal 4, UU NO. 18 Tahun 2012 tentang Pangan berisi tujuan UU pangan

${ }^{8}$ Jeane Neltje Saly, Pangan dan Tujuan Pemerintah Dalam Implementasi Hak Asasi Manusia, Journa de Jure, BPHN, 2007, hal. 15
} 
2. How is the government's efforts in implementing adequate food for the welfare of the people in Soe District TTS?

\section{Research Methods}

The type of research used is normative research, but in order to support the results of research used also supporting data obtained through empirical research to obtain empiric facts in the field. Empiric research is primarily used to obtain sufficient data on what constraints faced in the government's responsibility in providing food for the people, in carrying out its functions.

\section{Research Approach}

The type of research used is normative research, but in order to support the results of research used also supporting data obtained through empirical research to obtain empiric facts in the field.

Research Approach by using some research approach, that is approach of law (statute aproach) by reviewing various laws regulation that arrange Food. The second approach is the conceptual approach, which is done by exploring legal concepts, theories and legal principles related to government responsibility in the fulfillment of food. The third approach is the field approach through interviews to determine the constraints and efforts made by the government in carrying out its responsibilities in the field of food.

Types and Data Collection Techniques used in this study are secondary data. Secondary data is data obtained through literature study. This library study was conducted to find conceptions, theories, opinions, or related findings as well as with the subject matter.

Secondary data in this study include:

1. Primary legal materials in the form of the 1945 Constitution, Law of the Republic of Indonesia Number 18 Year 2012 on Food; Head of POM Regulation no. 1 Year 2015 on Food Categories; Head of POM Regulation no. 4 Year 2014 on the Maximum Limit of Additive Sweetener Material; Head of POM Regulation no. 38 of 2013 on the Maximum Limit of Antioxidant Food Additives; 37 of 2013 on the Maximum Limit of Dye Supplementary Material 281/5000Head of POM Regulation no. 36 of 2013 on the Maximum Limit of Supplemental Preservatives; Head of POM Regulation no. 4011 of 2009 concerning the Maximum Limit of Metal and Microbe Contamination; Head of POM Regulation no. 4057 Year 2004 regarding the Maximum Limit of Aflatoxin Contamination; Head of POM Regulation no. 1563 Year 2012 on Transgenic Food Products; Head of POM Regulation no. 100 Year 2008 on Organic Food; Head of POM Regulation no. 0475 Year 2005 on Nutritional Value Information on Food Label; Minister of Health Regulation no. 33 of 2012 on Food Additives; Minister of Health Regulation no. 701 Year 2009 on Iteradiated Food

2. Secondary legal materials are materials that are closely related to primary legal materials and can assist in the analysis and understanding of primary legal materials, which can be 
interviewed and so on. Tertiary legal material in the form of a Great Dictionary of Indonesian and other legal materials from the internet.

\section{Research Results And Discussion}

\subsection{Location Overview9}

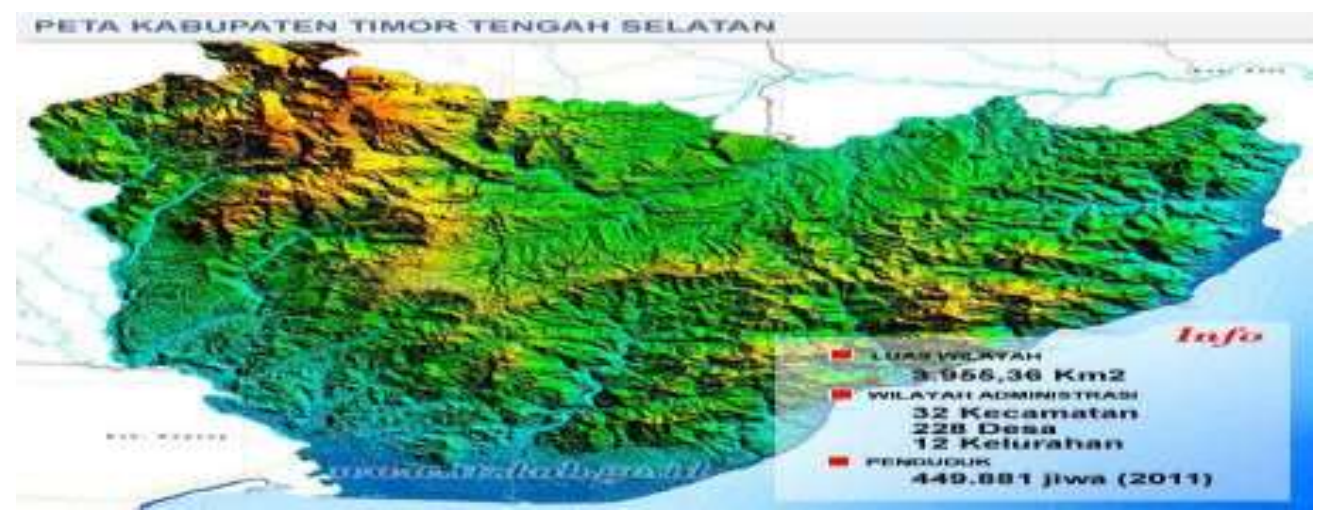

The Regency of Timur Tengah Selatan (TTS) located in East Nusa Tenggara (Figure), Geographically located at 9'26'- 10'10 'South Latitude, 124'49'01 "- 124'04'00" East Longitude , Regency Border Regency: Regency of North Timor in the north, Regency of Timor Tengah Utara in the east, Regency of Belu in the east, Regency of Kupang in the west and Timor Sea in the west. Area of 3,955.36 Kilometers, South Central Timor District is inland. It consists of 32 districts and 266 villages and 12 administrative municipalities.

Density population based on the size of the area, not the productive land, it seems that the rate of population growth as high as it has not become a problem. But the change in the orientation of the original builders based on agriculture, has changed the proportion of sources of livelihoods in general $\mathrm{NTT}^{10}$.

The climate in TTS Regency is basically dry (semi-arid) with hujanyang very short season during the months of November-March, and the drought between the months of April-October each year. Rainfall average 644,58mm/year which lasted from November to March with the number of raindays ranging from 100 to 150 days setahengan average air temperature ranges between $14 \mathrm{oC}-34 \mathrm{oC}$, air temperature average about $24.6 \mathrm{oC}$ and the highest air temperature of 33.7oC. While humidity the average monthly air is 85 percent, the highest humidity occurs in February and the lowest humidity. Climatic conditions are very influential on agricultural land management, because in general agricultural ecosystems in the TTS is a rain fed area that is managed only when the amount of water in the soil generally occurs in September ${ }^{11}$.

\footnotetext{
${ }^{9}$ Badan Pusat Statistik, Kabupaten Timur Tengan Selatan, Tahun, 2016

${ }^{10}$ Jeane NS, Hasil Penelitian Pangan 2015, Kerjasama Dengan Direktorat Penelitian HAM Kementerian Hukum Dan Ham, Jakarta 2015

${ }^{11}$ Op.,Cit, Laporan BPS Kabupaten Timur Tengah Selatan Tahun 2018
} 


\subsection{Vision and Mission ${ }^{12}$.}

"Vision:" The realization of the lives of South Timorese people who are Religious, Fair, Distinct, Advanced, Independent and Prosperous "

"Mission: To achieve the Vision of development, the MISI is set for South Central Timor development, realizing, among others: quality education standards and competitiveness; People's economic competitiveness gradually and sustainably; Facilities and infrastructure gradually and sustainably; Gender welfare and gender justice for the community;Sustainable technology development and sustainability management; Creativity and innovation of youth as a channel of interest and talent, and prosperous prosperous family life ".

The main food source, in the form of maize, is the main source of carbohydrate for Bakustulama people, so that corn is the dominant of their agricultural land which is sought so that the availability can be sufficient throughout the year. Although rice is also an important crop in the agro-ecosystem of TTS communities, corn remains a major source of food.

Type of corn planted by the farmer is the local corn, especially the white ones, much preferable because of the good taste. Hybrid corn is also grown, but only in part of the managed land. Hybrid corn is generally grown for sale or used as animal feed such as chicken, pork, and horse.

Farmers $^{13}$, recognize the benefits of hybrid corn that is high productivity, but low-saving power. In the traditional storage room, hybrid corn is more susceptible to warehouse pests, whereas local jagun can survive being stored until the next planting season.

Food storage techniques, which is usually done is to put corn still wrapped kelembot on the kitchen stove. So that every time the furnace is used, the heat from the furnace will be up to the corn stack. Every day they will take a number of maize savings to be processed further in accordance with the needs. Corn is consumed almost every day, especially by villagers with frequent meals 3 times a day. If they have a supply of rice, then the diet is usually the morning eating rice ${ }^{14}$.

\subsection{Legal Basis of Government Responsibility in the Fulfillment of People's Food}

The legal basis of government responsibility in the fulfillment of people's food is one of the legal efforts to overcome food insecurity. This is the mission of the state, especially developing countries in realizing development both at the center and in the regions, especially in the framework of regional autonomy continuously in a fair, directed and sustainable in realizing a just and prosperous society, both material and spiritual, based on Pancasila and the 1945 Constitution ${ }^{15}$.

The principle set forth as a guideline in its implementation is fair development. The indication is seen from the government's efforts in accelerating the achievement of indicators related to the millennium development goals (MDG's), through the national road map accelerating the achievement of the MDGsIn accordance with Presidential Instruction No. 3 of 2010 on Fair Development Program, the Guidelines for action plan to accelerate the achievement of MDGs objectives in the regions as the basis for planning and improving

${ }^{12}$ Laporan BPS Kabupaten Timur Tengah Selatan Tahun 2013

${ }^{13}$ Daud sebagai Petani jagunga dan bawng merah, penduduk Desa Nule Kabupaten TTS

${ }^{14}$ Op.,Cit. Tobias SEk, Desa Nule Kabupaten TTS

${ }^{15}$ Penjelasan Umum Undang-Undang Nomor 7 tahun 1996 tentang Pangan, diundangkan pada tanggal 4 Nopember Tahun 1996, Lembaran Negara Republik Indonesia Nomor 99 tahun 1996, Tambahan Lembaran Berita Negara Nomor 3656 
coordination to reduce poverty and improve the welfare of the people, among others, access to food marketing out of the region and the entry of activities from outside to the local food area.The allocation of funds to support the achievement of the MDGs will be continuously improved, including providing incentives and encouragement for local governments performing well in achieving the MDGs. Further strengthening mechanisms to improve the initiatives of Corporate Social Responsibility that support the achievement of the MDGs (Bappenas, 2010) ${ }^{16}$.

As a country with a large population and on the other hand having diverse natural resources and food sources, Indonesia is expected to be able to meet its sovereign and selfsustaining food needs ${ }^{17}$.

The Government and Local Government are determined to be responsible in such circumstances $^{18}$.

In carrying out these responsibilities the Government is obliged to manage the stabilization of supply and prices of Food Staples, to manage the Government's Food Staple Reserves, and the distribution of Basic Foods to realize the sufficiency of the safe and nutritious Food for the community ${ }^{19}$.

Although these responsibilities are pursued through the development, development, and / or assisting in the provision of community food stocks, developing, supporting, farmers' activities to produce food for their welfare, but not yet achieved optimally..

Solutions taken in addressing hunger or food scarcity cases are only temporary and even potentially add new problems such as rice imports and raskin programs. Another thing that becomes a problem is the delegation of responsibility for the availability of food to the community $^{20}$.

Related to the fulfillment and protection of the right to food as an element of the protection and fulfillment of human rights is essentially implicitly regulated in the 1945 Constitution even before the constitution is amended. Article 27 paragraph (2) states that: "Every citizen shall have the right to work and a decent living for humanity".Decent living means fulfilling the basic human need for clothing, food and shelter. Food regulation as trade commodity as regulated in Food Law is important to increase national food production competitiveness. However, the regulation in the framework of the fulfillment of the livelihood of the public is a fundamental right that should not be ignored, given the sustainability of economic development requires a harmony between the two.

The fundamental right which is a human right in the field of food recognized in the basic law of this country, internationally there is an agreement in the International Covenant on Economic and Socio-Cultural Rights (Covenant of Ecosob). Ratified by Indonesia since 28 October 2005 with the issuance of Law Number 11 Year 2005 on Ratification of the International Covenant on Economic, Social and Cultural Rights. The Covenant includes, among others, the responsibility of the state in respecting, protecting and fulfilling the right to food for its people.

Article 11 of the Covenant on Ecosystems states that "The States to the present Covenant recognize the right of everyone to a life worthy of himself and his family, including the

\footnotetext{
${ }^{16}$ Instruksi Presiden Nomor 3 Tahun 2010 tentang Program Pembangunan yang Berkeadilan

${ }^{17}$ Jeane Neltje Saly, Hasil Penelitian terkait dengan Penerapan Konvensi HAM Tentang Hak Di Bidang Politik

${ }^{18}$ Tanggung jawab Pemerintah tersebut diatur dalam Pasal 12

${ }^{19}$ Ibid Pasal 13

${ }^{20}$ Hal ini terdapat dalam Pasal 45 UU No. 18/2012 tentang Pangan, dimana dinyatakan bahwa Pemerintah bersama masyarakat bertanggung jawab untuk mewujudkan kerawananpangan
} 
appropriateness of food, clothing and shelter, and the improvement of the conditions of living continuously." Ecosaur rights are designed to ensure the full protection of human beings based on a view that human beings are entitled to enjoy the rights, freedom and social justice simultaneously ${ }^{21}$.

In 1992, the United Nations Food and Agriculture Organization, the Food and Agriculture Organization (FAO) and the World Health Organization (WHO) recognized that access to safe and nutritious food is the right of every individual ${ }^{22}$.

Various countries has its own food-related regulation to ensure that the food available is safe, as well as in ASEAN countries, also has its own food-related regulations such as Malaysia, Singapore and Thailand.Its implementation faces challenges with large populations facing very complex challenges in meeting the food needs of its population. Therefore, policy (stabilization) of food insecurity becomes a central issue in development and is the main focus in agricultural development. Increasing food demand along with increasing population and increasing employment opportunities for the population to earn a decent income for access to food are the two main components in the realization of food insecurity. The policy of consolidating food insecurity in this case includes the establishment of national food stability.Until the end of the 20th century still held the opinion that for the birth of state responsibility is not enough with the two elements above but there must be damage or loss (damage or loss) on the part or another country. However, in its development to date, it seems that the element of "loss" is no longer considered a necessity in every case for the birth of state responsibility.

For example, violations of international legal provisions relating to human rights are clearly acts that are blamed according to international law, although they do not harm other parties or countries, which in this study relate to the state's responsibility to respect, protect and fulfill the right to food for its people in the Ecosystem Covenant ${ }^{23}$.

The world has entered the era of globalization, full of regional and global competition. Indonesia's HR Challenge is a double nutrient burden in all life cycles ("across the life course")The impact of food and nutrition problems at an early age is not limited to nutritional status alone, such as short, obesity, and malnutrition, but much more broadly because it is associated with lower risk of intelligence, and the risk of non-communicable diseases in adulthood.

To overcome this, need multisector cooperation in the center-area so that: Pregnant women and nursing mothers no less eat, not thin, and not anemia; Children are not low birth weight, not short, not anemic; and Children and adults are not fatAlthough Accelerated Fulfillment of Food and Nutrition Community, but in practice has not been optimal. This is

${ }^{21}$ Dalam kovenan ini diatur bahwa negara memiliki kewajiban untuk menghormati (to Dalam konteks ini maka negara diletakkan sebagai aktor utama yang memegang kewajiban dan tanggung jawab (duty holders) mewujudkan hak-hak ekosob. Sementara warga negara adalah pemegang hak (rights holders) termasuk didalamnya adalah hak untuk mendapatkan perlindungan pangan. Oleh karena itu adalah sangat penting untuk memastikan bahwa hanya makanan yang aman yang dikonsumsi

${ }^{22}$ Food Safety, online: http://who.int/fsf.On the World Health Organization's Food Safety Programme. Diakses di Jakarta, 3 Nopember 2017 Dalam hubungannya dengan ini, perangkat hukum yang komprehensif sangat dibutuhkan untuk melindungi masyarakat dari resiko yang berhubungan dengan makanan karena ini bisa menjadi masalah yang serius

${ }^{23}$ Indonesia, Undang-Undang Nomor 11 Tahun 2005 tentang Pengesahan the International Covenant on Economic, Social and Cultural Rights, Lembaran Negara Republik Indonesia Nomor 118 Tahun 2005, Tambahan Lembaran Negara Republik Indonesia Nomor 4557. 
due to geographical conditions, rainfall of only $30 \%$ every year, dry soil conditions and lack of water resulted in food outcomes achieved not as expected.

Government Regulations (PP) No. 17/2015 on Food Security And Nutrition is made to be the cornerstone of food implementation and food security. The objective is to create the conditions for the fulfillment of Food and Nutrition needs for the state up to the individual, as reflected in the availability of adequate food, both quantity and quality, safe, diverse, fulfilling the adequacy of nutrition, equitable and affordable and not contrary to religion, belief and culture communities, to realize a good nutritional status in order to live healthy, active, and productive in a sustainable manner

To meet Food and Nutrition security in order to achieve the condition of the fulfillment of Food and Nutrition needs for the country up to the individual, so if domestic food is not sufficient, it can import from abroad but require the requirements. Among others are the requirements of security, quality, nutrition, and not contrary to the religion, beliefs, and culture of the community ${ }^{24}$.

In its implementation, the Government shall stipulate certain types and quantities of certain staple food as government food reserves as required, which is primarily domestic staple food. Basic Foodstuffs ${ }^{25}$, is referred to as "Certain Staple Foods" means Foods produced and consumed by the majority of Indonesian people when their availability and price are disrupted can affect economic stability and cause social upheaval in the community.

Government Food Reserves are periodically carried out taking into account the level of need. What is meant by the level of demand is the level of demand for the Government's Food Reserves is calculated by considering among others the ability of production, the number and distribution of population, consumption patterns, the level of consumption per capita, and the dynamics of international markets. The calculation of the level of need is set periodically ${ }^{26}$.

In order to increase the availability of diverse food to support the nutrition of the community, the local food becomes the mainstay. To be implemented, it is stipulated in a Government Regulation. Government regulations. Article 43 of Law no. 18/2012 about Food. determines that: The cornerstone of activities is set forth in Harmonization and Synchronization of RAN-PG 2015-2019 and RAD-PG, Directorate of Community Health and Nutrition - BAPPENAS. Archives delivered in the Revised Socialization of RAD-PG, and RAD-PG Governor Regulation Draft. East Nusa Tenggara Province

Food situation, which describes the condition of food distribution and access, And Third, the level of food consumption which describes the level of food utilizationIn relation to the responsibilities of local government, namely the South East South Government (TTS), Soe City, then the 7 (seven) things have been done, but not yet achieved optimally. It is as a result of insufficient human resources despite efforts made in the form of education, the culture of society that is less creative and feel comfortable with the existing situation, rainfall that does not reach the standard of meeting the needs of the plant.,

According to Sukirman Djahi ${ }^{27}$, Head of South East Middle East Food Office in Soe City, that in fact besides the geographical and rainfall conditions which are not supporting the achievement of the goal of accelerating the improvement of food and nutrition, is the

\footnotetext{
${ }^{24}$ Pasal 36 Undang-Undang Nomor 18 Tahun 2912 tentang Pangan

25 Penjelsan Pasal 28 Ayat (1), Undang-Undang Nomor 18 Tahun 2012 tentang Pangan tentang Penetapan cadangan Pangan

${ }^{26}$ Ibid., Ayat (2) penetapan Cadangan Pangan dengan memperhitungkan kebutuhan

${ }^{27}$ Drs Sukirman Djahi, Sekretari Dinas Ketahanan Pangan Kabupaten TTS di Soe, Wawancara terkait dengan Bagaimana Tanggung Njawab Pemerintah Daerah Dilaksanakan Di Wilayah Kabupaten Timus Tengah Selatan, Soe 10 Desember 2017
} 
Participation of the civilized society feel quite with their situation, even though it is in poverty level.Selanjutnya said that local government food reserves have not been optimally implemented inadequate connections, counseling related to the consumption of food diversification and nutrition improvement is done by way of counseling, even the village head is educated in Pusdiklat.

Although food crisis preparedness and food crisis management are given direction to the community to be able to store dry food in their barn which standard can survive until next season, supported by food distribution, food aid from central government in the form of Raskin but still not optimal to reach food sufficiency.To date, due to supervision, the local government oversees the implementation of food consumption of diversity and nutritional standards in order to improve public health through the Food and Nutrition Information SystemAccelerating food and nutrition compliance and food security is said by the Head of the Food Security Agency of the Ministry of Agriculture Agung Hendriadin on Food and Nutrition Strategic Policy (KSPG) through the preparation of the National Food and Nutrition Action Plan (RAN-PG) to all technical ministries and the preparation of the Plan Action of Food and Nutrition Area (RAD-PG) by Province and Regency ${ }^{28}$.

Furthermore, it is said that building food and nutrition is a very complex handling, so the need for harmonious cooperation from multi sectors. The three priorities of food and nutrition issues that must be addressed are the transformation of agriculture-food systems to the present conditions; the second point is the community's nutritional problems and up to the availability of land and wate.

To address these three issues, Agung requested that program planners and budgets focus on vulnerable areas of food insecurity based on maps of Food Security and Vulnerability. "In the Global Era, competition takes place in all areas of business, and the quality of human resources is a key factor in winning the competition, especially preparing healthy, qualified and qualified human resources in Indonesia," he said.According to him, in order to meet the adequacy of food and nutrition, supported by increased production that is ekperensial (not linear), with various efforts such as technological innovation, intensification, extensification, mentoring, business capital provision, and access to marketsAccording to him, in order to meet the adequacy of food and nutrition, supported by increased production that is ekperensial (not linear), with various efforts such as technological innovation, intensification, extensification, mentoring, business capital provision, and access to markets.

In order to fulfill the food and nutrition sufficiency of the Food Security Agency, the Ministry of Agriculture has several excellent programs, such as Sustainable Food Houses (KRPL), Food Self-Reliance Program (KMP) Program, and Food Consumption Diversification Movement aimed at increasing food production and nutrition improvement starting from the household.

Although the support of food and nutrition handling, not only by the Department that handles Food and Health, as well as private partnership agencies (SKPD) private institutions and even community agencies are involved in realizing food security and nutrition, but outcput achieved is still far from expectations

Though Indonesia as one of the center of biodiversity of the world store a wealth of flora and fauna abundant, some of which have the potential to be developed into food.

Technology can be utilized in better management, traditional foods such as kaledo or papeda can be further developed, in addition to improving its nutritional content, as well as to

${ }^{28}$ Agung, Workshop Pemantauan dan Evaluasi Rencana Aksi Daerah Pangan dan Gizi Provinsi Regional Tengah dan Timur di Yogyakarta, Jumat (24/11) 
reach a wider market beyond its traditional consumers. So traditional foods such as kaledo and pepeda are also available in other areas. The "enrichment" of traditional foods such as kaledo, maize, not only promotes indigenous Indonesian food, more importantly improves food security by reducing dependence on rice $^{29}$.

Mexican country also has a traditional food called tortila.Every day the inhabitants of the countryside this country preparing tortillas, is like cooking rice for the community in Indonesia.Tortila made by utilizing one of Mexico's natural wealth of corn.History records show that from this country the origin of corn that is now scattered throughout the world. Interestingly, tortillas that used to be traditional food in rural areas, are now also consumed by the urban population and even penetrate into a number of other countries such as the United States. Better technology and management changed the image of tortillas from "village people" food to "modern food".

Residents in modern countries are now more careful to determine what type of food to consume. In addition to taste, they also began to consider the effects of these foods on health for the long term, as well as the impact of the food production process on environmental sustainability. Gradually they begin to abandon conventional foods like fast food and strive to return to traditional.

Some choose to become vegetarians with the consideration of the resources needed to produce animal food much more than vegetable foods. Down to Earth, one of the institutions supporting vegetarian lifestyles, says that to produce one calorie of beef requires 78 times the energy needed to produce one calorie of soybeans ${ }^{30}$.

In contrast to the trend in developed countries, various types of fast food foods, especially international fast food, are now growing and flourishing, flooding major cities in Indonesia and competing with traditional foods.

\subsection{Implementation of Government Responsibility in TTS District}

\section{a. The existence of Local Food Agriculture of TTS Soe Regency}

In relation to food security efforts in the region of Middle East District Selata, then made various efforts by the Regional Government in this case the Office of Food Knowledge in Soe. The existence of the Government of TTS Regency, Soe, in relation to local food agriculture to meet the needs of the community is as illustrated below, namely Type of Food Crop

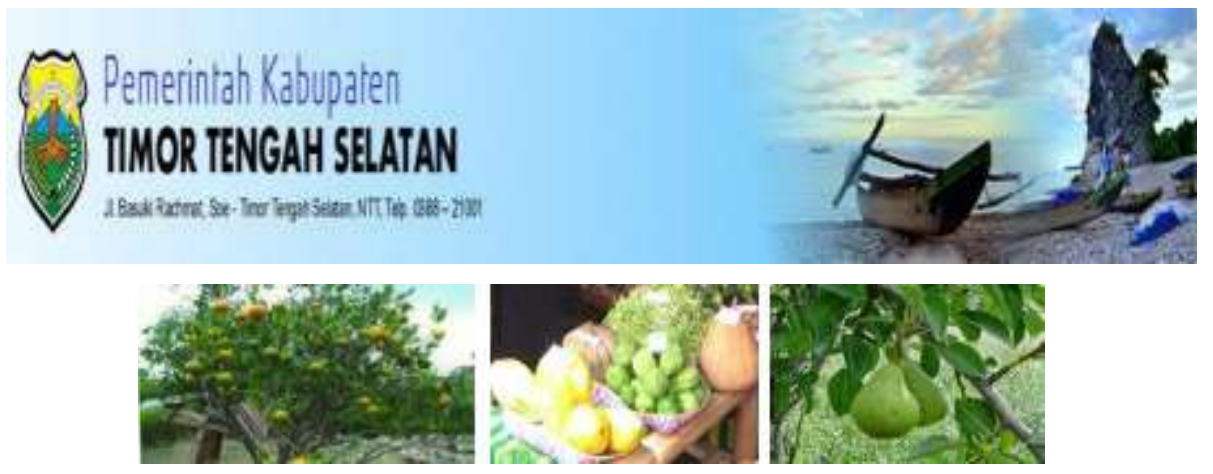

\footnotetext{
${ }^{29}$ Jeane N Slay ,Down to the Eart, Hasil Penelitian :Agribisnis. Lingkunga Hidup dan Keberlanjutan Hidup Manusia, Bahan Kuliah Lingkungan Hidup, Pustaka Abadi, Jakarta, 2012, hal. 2

${ }^{30}$ Jeane N Slay, Ibid, hal.3
} 
To meet the needs of food in the household, the community South Central Timor District developing the type of food crops that have been cultivated by the previous generation with the main product is corn crops. While rice cultivated by the community in some areas depends on the availability of water, while other types of plants such as tubers, bananas and legumes developed by the community as an alternative crop in anticipating crop failure due to uncertain weather.

Other than that rice plant is also cultivated by the people of South Central Timor District in some areas along the River Basin which has been built irrigation channels with varying planting time, depending on the availability of water with 3.123 ha of harvested area produces 10,656 tons of dry unhulled rice as much as 7,106 tons of rice. While rice field with dried grain milled as much as 276 tons and Rice as much as 184 tons.
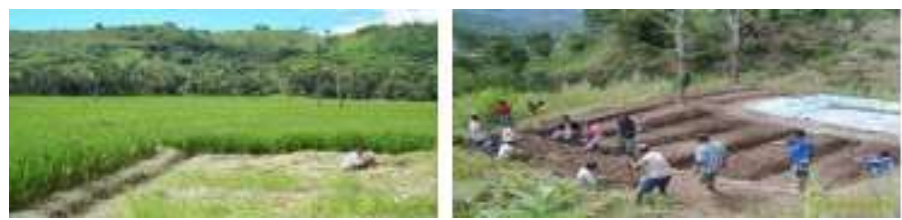

Datafrom the Secretariat of Soe City Food Office, February, 2017 Production of Wetland Rice in TTS District in 2014.

While other types of plants such as tubers, bananas and legumes are still developed as alternative communities anticipate crop failure due to uncertain weather.

Especially for this type of vegetable crops, most of the people have developed for an income-increasing orientation through sales in the market. Types of commodities such as cabbage, onion, spring onions, carrots and red beans not only dominate in the district market but also have dominated supply for some markets in Kupang City, the capital of NTT Province.

Several types of fruit plants in South Central Timor District have considerable potential and have economic prospects or value as a commodity such as avocado, mango, guava, papaya, pineapple banana, jackfruit, soursop, orange and watermelon. As it is known that the SoE Tangerines Citrus is one commodity that must be cultivated area professionals to improve household incomes and the and economy in area.

\section{b. Problematic and Solutions}

Problematic emerging, that is. not only lack of understanding of government apparatus including co-chairs related to independent food business, but also weather conditions. These conditions have an effect on the lack of effective assistance. LKD and TPD resulted in the objectives of food fulfillment is less successful. Solution is done through food imports. This situation occurs also in other countries, as in China.

As a result of the weather, China now imports many food from abroad, causing industrial worries on food security. In "Laporam The Giobal Food Security Index" in 2016, China is ranked 42nd, while western countries occupy the top blessing in global food safety ratings. Rank far beyond China (18), which is highly dependent on food imports, Korea ${ }^{31}$.

In Indonesia, especially TTS Regency, although the government has tried to apply local food, but the increase of business activities in Desa Mandiri Pangan has not been optimally

31 EPOCH TIMES, Krisis Tiongkok Berikutnya Krisis Pangan? http://www.erabaru.net/2016/10/14/krisis pangan, Dieksis di Jakarta, 16 April 2018 
achieved. This problematic cause of food fulfillment through central government subsidy which actually also is imported product.

If applied, more productive crops related to maize in the solution to the constraints faced are also one good solution, as in terms of global warming impact introduced by Japan ${ }^{32}$.

Currently implemented in the Bekasi region, in collaboration with Japanese plant physiologist Shigeharu Shimamura built the largest indoor farm in Miyagi Prefecture. The former Sony factory has now been transformed into a high-tech hydroponic farmhouse that allows workers to harvest thousands of lettuce each day. In overcoming the world's starvation of food production technologies. Some biologists think mutant corn may be the answer. A way to exploit natural genetic mutations and then cross-fertilize mutant maize with traditional corn crops to produce larger corn kernels without changing other aspects of the corn, as shown in the following figure.Cara untuk mengeksploitasi mutasi genetik alami dan kemudian melakukan pembuahan silang jagung mutasi dengan tanaman jagung tradisional untuk menghasilkan biji jagung yang lebih besar tanpa mengubah aspek lain dari jagung tersebut, sebagaimana terlihat dalam gambar berikut.

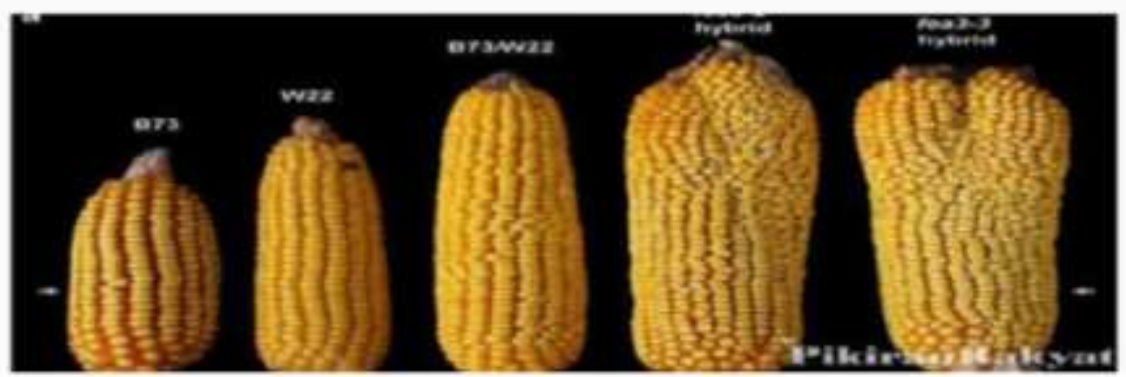

Figure 1. Corn is the result of genetic manipulation,

The result is a 50 percent increase in crop yields. A surprising result for a struggling agricultural area meets food demand with limited areas. Although the breakthroughs have not been tested outside the laboratory, scientists have been looking for ways to utilize the same genetic mutations in other staple crops such as wheat and rice.

There is a problematic in the business run group does not look at the potential area (Village). Thus, the resulting product can not be marketed to a wider market or not marketoriented. In general, the efforts undertaken in TTS, Soe, in the form of business activities of self-sufficient villages of food, which in fact:

Food processing business 3\%, Livestock Business 35\%, Fishery Business 12\%, Agriculture Business 45\%, Other Business 5\%.

The solutions are:

a. Strengthen the understanding to government officials and assistant officers to achieve optimization in mentoring

b. TPD guidance for performance improvement

c. Development of productive business groups in accordance with the potential area in Soe TTS.

32 Shigeharu Shimamura, Research Report of Indoor Cultivation for the Future, The University of Arizona, 2014 
Although less than optimal achievement of food fulfillment objectives, but the local government continues to do business throughout the region by way of Development of Food Self-Village, by Cluster, and Stages of development, namely:

a. Cluster which is a collection of similar business activities that interact and interdependence from upstream to downstream sectors which is a collection of similar business activities that interact and interdependence from upstream to downstream sectors

b. Cluster development stage, namely: Understanding the potential of economic development of villages, Cooperation, Management and improvement of services. Encouragement of innovation and entrepreneurship, marketing of village production Prinsip

Principles of Cluster-Based Cluster Development in the form of: leading sectors, according to regional characteristics, carried out in a comprehensive and continuous integrated and sustainable manner, and implemented in accordance with the principles of autonomy and decentralization

Furthermore, according to Sukirman Djahi as the Secretary of Food Agency, the efforts made by the Regional Government are the Sharpening of General Guidelines with Stronger and Measurable Output in several stages, namely Preparation, RUK Formulation, Market and Network Development, and Strengthening Community Savings, Independence and Reduction of Facilitation Facilitators can be independent.

In the realization of Food Sovereignty, Food Self-Reliance, and Food Security, it is necessary to have a food institution that has authority in building coordination, integration, and synergy across sectors. The institute carries out the task of government in the field of Food, which is under and responsible to the President.

In realizing food sovereignty, food self-sufficiency and food security, communities can participate through the implementation of production, distribution, trade, food consumption, the organization of public food reserves, prevention and prevention of food and nutrition, information and knowledge of food and nutrition, Provision of Food Availability, Food Affordability, Food Diversification,

Food Safety, and / or Increased Independence of Household Food. Communities may also address issues, inputs, and or settlement of food issues to the Government and Local Government. The Law on Food is intended as a legal basis for Food Implementation which includes Food Planning, Food Availability, Food Affordability, Food and Nutrition Consumption, Food Security, Food labels and advertisements, Supervision, Food information systems, Food research and development, Food institutional, community participation, and investigation According to A Patra M Zen, the fulfillment of basic rights such as food, health, housing, employment and education shall be or is the responsibility of the state, the State is responsible for facilitating and providing welfare for the people, such as eating mminum dwelling etc., members of the community. Therefore, the international community is pushing EKOSOB's rights not only into human rights, but also as legal rights ${ }^{33}$.

Article 24 of the Ecosoc on Human Rights states that any State Party may submit an objection to another State Party without requiring that the State party to the objection as a victim of a human rights violation committed by the State accused of the offense.

${ }^{33}$ A Patra M Zen, Justisiabilitas Hak-Hak Ekonomi, Sosial dan Budaya: Menarik Pengalaman Internasional, Mempraktikkannya di Indonesia, Jurnal HAM Komisi Nasional Hak Azasi Manusia, Vl. 1 Oktober 2003, hlm. 38 
Article 3 of the draft convention on state responsibility created by the International Law Commission (ILC) removes.

Frans Magnis Suseno states that the rule of law has four characteristics. First, the government acts solely on the basis of applicable law. Secondly, the community can appeal in court against the government's decision and the government is obedient to the judge's decision. Third, the law itself is just and guarantees human rights. Fourth, the power of judges is independent of the will of the government ${ }^{34}$.

According to Sri Soemantri, the most important elements of the state law are four, namely (1). That the government in performing its duties and obligations must be based on law or regulation; (2) a guarantee of human rights (citizens) (3). the division of power within the state; (4) the supervision of the judicial bodies adanya pengawasan dari badan-badan peradilan $^{35}$.

In addition, according to Jimly Asshiddiqie, there are twelve basic principles of the state law. The twelve basic principles are the main pillars that support the stand up of a modern state so that it can be called a state of law in the real sense. The twelve principles are (1) the supermacy of law, (2) equality before the law, (3) the rule of law, (4) the limitation of power, (5) independent executive organs, (6) free and impartial courts, (7) state administrative courts, (8) administrative justice negara (constitusional court), (9) peradilan hak asasi manusia, (10) democratic (democratische rechtsstaat), (11) serves as a means of realizing the goals of the state (welfare rechtsstaat), and (12) transparency and social control.

Bagir Manan, in Arif Sidharta, elements and basic principles of the rule of law are as follows: (1) Recognition, respect and protection of human rights rooted in respect for human dignity (Human Dignify). (3) The principle of legal certainty. The state of law aims to ensure that legal certainty is manifested in society. (4) The principle of Similia Similibus (principle of equation). In a state of law, the government should not privilege any particular person (must be non-discriminatory). (5) The principle of democracy. The principle of democracy provides a means or method of decision-making. This principle requires that everyone should have equal opportunity to influence government action. (6) Government and government officials carry out public service functions. Related to the government's responsibility in fulfilling the people's food, then what is done by the government has not been optimal even though various efforts have been done.

\section{Conclusions And Recommendation}

\subsection{Conclusions}

1. Obstacles to implement the responsibilities of the Regional Government to fulfill the right to food as the basic needs of the people of NTT South East Regency Regency (TTS) is in addition to geographical conditions, rainfall, clean water, human resources are still far from expectations both in quality and quantity, transportation, and infrastructure for communication from village to village to marketing site, also facing increasingly complex food challenges, constantly changing from time to time and being influenced by matters of its nature both locally and globally. Changes and differences such as the actual condition

\footnotetext{
${ }^{34}$ Franz Magnis Suseno, Etika Politik (Pinsip-prinsip moral dasar kenegaran modern), Cet. 7., (Jakarta: PT Gramedia, 2003), hlm. 295

${ }^{35}$ Sri Soemantri, Bunga Rampai Hukum Tata Negara Indonesia, (Bandung: Alumni, 1992), hlm. 29-30
} 
of society, the dynamics of population, the development of science and technology, the information revolution, telecommunications, transportation, democratization, decentralization, and of course globalization, are the determinants of food as the basis for national anticipation. The problem of food security experienced by Nusa Tenggara Timur is actually an irony because this region is not poor natural resources. Food availability is not the only determinant of food security, and NTT has the potential to be utilized in order to achieve food security missions.

2. Efforts made by City District Government to achieve food self-sufficiency through local produce, in the form of Institutional Strengthening. And Business Development followed by post-independence stages in the form of General Guidance Sharpening with Stronger and Measurable Output in the stages to be exported, at least in order to enjoy the ASEAN community market. Further enhancement and expansion of business network and capital access through the strengthening of business capital by way of innovation of processed food product and development of marketing network of Mandiri Pangan Village group and education for functional assistant and encourage community attitude toward habit to become culture of understanding and movement toward self-food security as well as the socialization of 4 healthy five perfect through the utilization of food in the region to make them prosperous.

\subsection{Recomendation}

1. In order to fulfill the government's responsibility in the fulfillment of people's food in TTS, it is necessary to deeply study the phenomenon of food security in NTT from micro scale so that the understanding of the phenomenon in society can be obtained better. Food security is a successful condition of food availability, access to food, food utilization and stability of access to food. Thus the commitment of both the central government and local governments to achieve the realization of local food as a daily staple with the socialization of long-term benefits for the welfare the community to reduce the attitude of living that feels enough with its existence to be able to utilize the existing land in the long term can be exported by way of working partnership of large capital business with agricultural working group..

2. Optimizing the creation of infrastructus as a means of communication and transportation of food products to the marketing area, as well as the addition of the quality and quantity of functional staff of chocal food business facilitators and their utilization for their welfare towards food self-sufficiency.penciptaan infrastruktus sebagai sarana komunikasi dan pengangkutan hasil pangan ke wilayah pemasaran, serta penambahan secara kualitas dan kuantitas tenaga fungsional pendamping usaha pangan klokal dan pemanfaatannya bagi kesejahteraan mereka menuju kemandirian pangan.

\section{References}

[1]. A Patra M Zen, Justisiabilitas Hak-Hak Ekonomi, Sosial Dan Budaya: Menarikpengalaman Internasional, Mempraktikkannya Di Indonesia, Jurnal HAM Komisi Nasional Hak Azasi Manusia, Vl. 1 Oktober 2003

[2]. A.V. Dicey, An Introduction To The Study Of The Law Of The Constitution, (London: English Language Book Society And Macmillan, 1971), 
[3]. Arthur Gayer And Anna Schwartz,Growth And Fluctuations In The British Economy, 1790-1850: An Historical, Statistical, And Theoretical Study Of Britain's Economic Development, With 1953 ISBN 0-06-492344-4

[4]. A.V. Dicey, An Introduction To The Study Of The Law Of The Constitution, (London: English Language Book Society And Macmillan, 1971),

[5]. B Arief Sidharta, "Kajian Kefilsafatan Tentang Negara Hukum", Jentera, (Edisi 3 Tahun II, November 2004).

[6]. Cohn, Steven Mark (2006). Reintroducing Macroeconomics: A Critical Approach M.E.Sharpe.Hlm. 111.ISBN 0-7656-1450-2 Davis

[7]. Chris Giles In London, Ralph Atkins In Frankfurt And Krishna Guha In Washington."The Undeniable Shift To Keynes".Financial Times.Diakses Tanggal 23 January 2009.

[8]. Edward Nelson, "Friedman's Monetary Economics In Practice," Finance And Economics Discussion Series, Divisions Of Research \& Statistics And Monetary Affairs, Federal Reserve Board, April 13, 2011

[9]. Franz Magnis Suseno, Etika Politik (Pinsip-Prinsip Moral Dasar Kenegaran Modernmodern), Cet. 7.,(Jakarta: PT Gramedia, 2003),

[10].Jimly Asshiddiqie, Konstitusi\& Konstitusionalisme Indonesia,(Jakarta:Sekretariat Jendral Dan Kepaniteraan Konstitusi RI, 2006)

[11].John Maynard Keynes Time Value Of Money."How Changed The World Ofeconomics". Investinganswers.Diakses Tanggal 2 October 2017

[12].P. J. Kelly Utilitarianism And Distributive Justice: Jeremy Bentham And The Civil Law. (USA, Oxford.(1990)).

[13].Suwarsono, Alvin Y.So (1991).Perubahan Sosial Dan Pembangunan Di Indonesia: Teori-Teori Modernisasi, Dependensi Dan Sistem Dunia. Lembaga Penelitian, Pendidikan Dan Penerangan Ekonomi Dan Sosial

[14].Winahyu Erwiningsih, Peranan Hukum Dalam Pertanggungjawaban Perbuatan Pemerintashan (Bestuurshendeling) Suatu Kajian Dalam Kebijakan Pembangunan Hukum

[15].William L, Bob Figgins, David Hedengren, And Daniel B. Klein. "Economic Professors' Favoriteeconomic Thinkers, Journals, And Blogs," Econ Journal Watch 8(2): 126-146, May 2011. Dan Daniel Yergin \& Joseph Stanislaw."Book Extract From The Commanding Heights" (PDF). Public Broadcasting Service.Diakses Tanggal 13 November 2017.

\section{Journal Dan Makalah:}

[1]. Alexandre Kojeve, Introduction To The Reading Of Hegel: Lectures On The Phenomenology Of Spirit.ISBN 0-8014-9203-3 Penafsiran Eropa Yang Berpengaruh Tentang Hegel.

[2]. Ahmad Suryana, Kebijakan Kerawanan Pangan Nasional, Makalah Disampaikan Pada Simposium Nasional Kerawanandan Keamanan Pangan Pada Era Otonomi Dan Globalisasi, Faperta, IPB, Bogor, 22 November 2005.

[3]. A Patra M Zen, Justisiabilitas Hak-Hak Ekonomi, Sosial Dan Budaya: Menarik Pengalaman Internasional, Mempraktikkannya Di Indonesia, Jurnal HAM Komisi Nasional Hak Asasi Manusia, Vl. 1 Oktober 2003.

[4]. Avineri, Shlomo, .Hegel's Theory Of The Modern State.Cambridge University Press. Pengantarterbaik Ke Dalam Filsafat Politik Hegel.1074, Terjemahan Budianto, Rajagrafindo.Jogyakarta, 2011

[5]. Chris Giles In London, Ralph Atkins In Frankfurt And Krishna Guha In Washington."The Undeniable Shift To Keynes".Financial Times.Diakses Tanggal 23 November January 2017

[6]. Edi Suharto, Ph.D., Negara Kesejahteraan Dan Reinventing Depsos, Makalah Disampaikan Pada Seminar Yang Bertajuk "Mengkaji Ulang Relevansi Welfare State Dan Terobosan Melalui Desentralisasi -Otonomi Di Indonesia, Yogyakarta, Tahun 2006

[7]. Daniel Yergin \& Joseph Stanislaw."Book Extract From The Commanding Heights"(PDF).Public Broadcasting Service."How To Kick-Start A Faltering Economy The Keynes Way".BBC. 22 October 2008. Diakses Tanggal 13 November 2008 
[8]. John Maynard Keynes Time Value Of Money."How Changed The World Of Economics". Investinganswers.Diakses Tanggal 2 October 2017

[9]. John Alder, Constitutional And Adminitrative Law, (London: Macmillan Educations Ltd, 1989),

[10].Milton Friedman". Commanding Heights.PBS. October 1, 2000. Diakses Di Jakarta Tanggalseptember 19, 2017

[11].Iskatrinah, Pelaksanaan Fungsi Hukum Administrasi Negara Dalam Mewujudkan Pemerintahan Yang Baik, Litbang Pertahanan Indonesia, Balitbang Dephan 2004.

[12].Jeane NS, Pemanfaatan Istilah Dalam Pembuatan Artikel Hukum, Pemakalah Dalam Diskusialumni Mahasiswa Pascasarjana UPN Jakarta 2012,

[13].........Hasil Penelitian Terkait Dengan Penerapan Konvensi HAM Tentang Hak Di Bidang Ecosob, De Jure, BPHN, Jakarta, 2016

[14].J. Michael Armer, John Katsillis. "Modernization Theory,Jakarta, Diakses 10 Desember 2017

[15].John Alder, Constitutional And Adminitrative Law, Macmillan Educations Ltd, London:1989

[16].Klaster Argo, Kerawanan Dan Keamanan Pangan, Konsep Ketahanan Dan Keamanan Pangan | Art Blog'sabadiart.Blogspot.Co.Id > Sains2005., Diakses Di Jakarta, 6 Nopember 2017

[17].Laurence Dickey, 1987. Hegel: Religion, Economics, And The Politics Of Spirit, 1770- 1807. Cambridge University Press.ISBN 0-521-33035-1

[18].Lilik Mulyadi, Teori Hukum Pembangunan,Prof. Dr. Mochtar Kusumaatmadja, S.H., L1.M.*) Sebuah Kajian Deskriftif Analitis, Alumni Bandung. 2005

[19].Mochtar Kusumaatmadja, Hukum, Masyarakat, Dan Pembinaan Hukum Nasional, Penerbit Binacipta, Bandung, 1995

[20]...........,Pembinaan Hukum Dalam Rangka Pembangunan Nasional, Penerbit Binacipta, Bandung, 1986,

[21].Neil Smelser, Economy And Society: A Study In The Integration Of Economic And Social Theory. (With Talcott Parsons) (1956)

[22].Otje Salman Dan Eddy Damian (Ed), Konsep-Konsep Hukum Dalam Pembangunan., Penerbit PT.Alumni, Bandung, 2002,

[23].William L, Bob Figgins, David Hedengren, And Daniel B. Klein. "Economic Professors'Harvard Univ Published, USA

[24].Krugman, Peddling Prosperity: Economic Sense And Nonsense In An Age Of Diminished Expectations (1995) P 43 Online, Jakarta, September 2017

[25].Edward Nelson, "Friedman's Monetary Economics In Practice," Finance And Economics Discussion Series, Divisions Of Research \& Statistics And Monetary Affairs, Federal Reserve Board, April 13, 2011

\section{Peraturan Perundang-Undangan:}

[1]. Undang-Undang Nomor 7 Tahun 1996 Tentang Pangan, Diundangkan Pada Tanggal 4 Nopember Tahun 1996, Lembaran Negara Republik Indonesia Nomor 99 Tahun 1996, Tambahan Lembaran Berita Negara Nomor 3656.

[2]. Undang-Undang Nomor 11 Tahun 2005 Tentang Pengesahan The International Covenant On Economic, Social And Cultural Rights, Lembaran Negara Republik Indonesia Nomor 118 Tahun 2005, Tambahan Lembaran Negara Republik Indonesia Nomor 4557.

[3]. Undang-Undang Nomor 11 Tahun 2005 Tentang Pengesahan The International Covenant On Economic, Social And Cultural Rights, Lembaran Negara Republik Indonesia Nomor 118 Tahun 2005, Tambahan Lembaran Negara Republik Indonesia Nomor 4557. 